\title{
RETROSPECTIVE ANALYSIS OF THE BLUETONGUE OUTBREAK IN SERBIA
}

\author{
Spomenka Djurić1, Predrag Simeunović ${ }^{2}$ Milorad Mirilović1 Jevrosima Stevanović3 \\ Uroš Glavinić ${ }^{3}$, Branislav Vejnović ${ }^{1}$, Zoran Stanimirović ${ }^{3}$ \\ ${ }^{1}$ Department of Economics and Statistics, Faculty of Veterinary Medicine \\ University of Belgrade, Bul. Oslobodjenja 18, 11000 Belgrade, Serbia \\ ${ }^{2}$ Department of Ruminants and Swine Diseases, Faculty of Veterinary Medicine \\ University of Belgrade, Bul. Oslobodjenja 18, 11000 Belgrade, Serbia \\ ${ }^{3}$ Department of Biology, Faculty of Veterinary Medicine, University of Belgrade \\ Bul. Oslobodjenja 18, 11000 Belgrade, Serbia
}

Received 27 January 2016; Received in revised form 20 August 2016; Accepted 10 October 2016

\begin{abstract}
Bluetongue, a vector-born disease caused by the Bluetongue virus (BTV) and transmitted by Culicoides biting midges, is considered to be one of the most important diseases of domestic ruminants. The first outbreak of bluetongue in Serbia was reported in 2001, when BTV serotype 9 was identified in sampled materials. In 2014, outbreak of BTV-4 in Serbia caused considerable economic losses affecting sheep, cattle and goats. During this outbreak, BTV-4 was recorded in 644 outbreaks within 49 municipalities, part of 17 administrative regions. From the total number of sheep kept in areas affected by bluetongue ( $\mathrm{n}=1748110), 2083$ cases $(0.2 \%)$ were proven to be BTV-4 infected. Total of 206 infected cattle and 24 infected goats were reported during this investigation period, which represents $0.06 \%$ and $0.03 \%$ of the total number of cattle and goats kept in affected areas, respectively. The highest incidence of infected sheep, cattle and goats was recorded on the territory covered by veterinary institute of Nis. Recorded lethality in cattle, sheep and goats was $18.45 \%(\mathrm{n}=38)$, $48.10 \%(n=1002)$ and $54.17 \%(n=13)$, respectively. The peak of the outbreak was in September and October when $94.43 \%$ of the confirmed positive cases, regardless of the species, was recorded. Monitoring of bluetongue disease in Serbia relies on active surveillance programmes aimed at: (i) identification and tracing of susceptible and potentially infected animals and (ii) detection, distribution and prevalence of insect vectors. Vaccination of sheep is planned to be implemented as a control measure against bluetongue in Serbia.
\end{abstract}

Key words: bluetongue, BTV-4, outbreak, Serbia

\section{INTRODUCTION}

Bluetongue (Febris catarrhalis ovium) is a noncontiguous vector-borne viral disease of domestic and wild ruminants with a wide distribution and considerable impact on the health status and production $(1,2)$. The disease is caused by the Bluetongue Virus (BTV), a double stranded RNA

Corresponding author: Dr. Spomenka Djurić, $\mathrm{PhD}$

E-mail address: spomenkadj@vet.bg.ac.rs

Present address: Department of Economics and Statistics

Faculty of Veterinary Medicine, University of Belgrade

Bul. Oslobodjenja 18, 11000 Belgrade, Serbia

Phone: +381112685551; +381628025060

Copyright: (C) 2016 Djurić S. This is an open-access article published under the terms of the Creative Commons Attribution License which

permits unrestricted use, distribution, and reproduction in any medium, provided the original author and source are credited.

Competing Interests: The authors have declared that no competing interests exist.

Available Online First: 15 November 2016

Published on: 15 March 2017

http://dx.doi.org/10.1515/macvetrev-2016-0094 virus of the Orbivirus genus in the Reoviridae family $(3,4)$. There are currently 26 different BTV serotypes (5). The most important route of BTV transmission is primarily through the bite of haematophagous midges of the genus Culicoides (Diptera: Ceratopogonidae), the major biological vector of the virus $(6,7)$. In endemic regions the disease displays a seasonal pattern, with highest incidence in late summer when the vector population reaches its peak (8). The severity of clinical symptoms depends mainly on the infected host, the virulence of the BTV strain and the immunological status of the affected animals $(2,3)$. The clinical form of bluetongue is most commonly observed in domestic sheep, and it is characterised by fever, excessive salivation, hyperaemia of the nasal and labial mucous membranes, oedema and swelling of the face, severe dyspnoea, asphyxia, oedemas and a blue swollen tongue partly hanging out of the 
mouth $(9,10,11)$. In cattle, goats and wild ruminants, bluetongue is most often present in a subclinical form or with mild or transient clinical signs $(2,12)$. Occurrence of bluetongue is closely related with the activity of competent Culicoides vectors, thus the emergence of this disease was traditionally reported in a geographic band between the latitudes $40^{\circ} \mathrm{N}$ and $35^{\circ} \mathrm{S}$, which is its natural habitat (14).

Until 1998, only short outbreaks of bluetongue were occasionally recorded in South European countries (10). However, after nearly 20 years of absence BTV was recorded again on four Greek islands, where BTV-9 was isolated and that was the first report of this serotype on the European continent $(15,16)$. Since 1998, multiple emergences of bluetongue have been evidenced in Southern Europe, caused by various serotypes of the virus: 1, 2, 4, 8, 9, 10 and 16 (14, 17, 18). From 2006-2010 an epidemic of bluetongue caused by BTV serotype 8 was recorded in many countries of Central and Northern Europe $(14,17,19)$. There have been indications that serotypes BTV-6 (detected in Germany and Holland) and BTV-11 (detected in Belgium) could have been introduced by illegal import of live attenuated vaccines $(20,21)$, as no virus has been isolated and no clinical signs of bluetongue disease have been observed (22).

The first report of bluetongue in Serbia was in 2001 (23), when BTV-9 was detected. In the same year, BTV-9 positive cases were also reported in Bulgaria, Macedonia, Montenegro and Croatia (10, 24, 25), and in the following year, the same serotype was confirmed in Bosnia and Herzegovina (10). In September 2014, following the outbreak of clinical symptoms of bluetongue in sheep and cattle in Serbia, the Institute of Veterinary Medicine Belgrade (Serbia) and the Pirbright Reference Laboratory (England), confirmed the presence of BTV-4 for the first time in this country. Date of the first confirmed case was September 3, 2014 (http://www.oie.int/wahis_2/public/wahid. php/Reviewreport/Review?reportid=15987). The outbreak of BTV in Europe has caused considerable economic losses, including not only direct damage due to mortality and reduced production, but also indirect damage because of trade bans of ruminants between BTV infected and non-infected areas (17, 26). Due to the increasing importance of bluetongue, the fast spreading of the causative agent and the abovementioned direct and indirect losses, this disease has been included in the List A of notifiable diseases compiled by the OIE (27).

This paper presents a retrospective analysis of the incidence and geographical distribution of BTV in sheep, cattle and goats in the 2014 BTV outbreak in Serbia.

\section{MATERIAL AND METHODS}

\section{Investigation of BTV positive animals}

The epizootiological situation on Serbian territory is under the surveillance of 12 veterinary institutes, where each institute covers specific area (Fig. 1). The presence of bluetongue was investigated in sheep, cattle and goats. Detection of clinically infected animals throughout Serbian territory was carried out in a joint action by field veterinarians, specialists from veterinary institutes and representatives of the Veterinary Directorate (Ministry of Agriculture and Environmental Protection of Republic of Serbia). In an extensive action that lasted from 03.09 - 31.12.2014, all cases suspected for bluetongue disease were reported by field veterinarians to the veterinary institute responsible for each district. Blood sample from each suspect animal was subjected to serological and molecular testing according to the recommendation from OIE (28). Subsequently, blood from the rest of animals from herds with confirmed BTV positive cases was also tested in the same manner. Testing for the presence of antibodies against BTV was performed using BTV antibody competitive ELISA (cELISA) (IDVET, Montpellier, France). In each seropositive case detection of BTV RNA was performed using real-time RT-PCR (29). All laboratory analyses were performed by the National Reference Laboratory for bluetongue disease, The Institute of Veterinary Medicine - Belgrade (Serbia).

\section{Statistical analysis}

Results are shown in a form of descriptive statistical parameters. Differences were tested using t-test in cases of two independent samples. Data analysis was performed using software package PASW Statistics 18.

\section{RESULTS}

In 2014, 644 outbreaks were reported in 49 municipalities in 17 (out of 29) administrative regions in Serbia (source: Veterinary Department, Ministry of Agriculture and Environmental Protection, Republic of Serbia, http://www.oie.int/wahis_2/public/ wahid.php/Reviewreport/Review?reportid=15987). Bluetongue cases were confirmed on territories under the surveillance of the following 9 veterinary institutes: Nis, Pozarevac, Zajecar, Pancevo, Zrenjanin, Kraljevo, Sabac, Jagodina and Belgrade (Fig. 1). From the total number of animals with clinical signs of bluetongue, $91.45 \%$ were positive on cELISA testing. Results of molecular identification confirmed the presence 
Retrospective analysis of the bluetongue outbreak in Serbia

of BTV virus serotype 4 in $56.78 \%$ of seropositive samples. With regards to the total number of susceptible animals (1 484 725) kept in the areas of BTV outbreak recorded in 2014, the overall incidence proportion of BTV in Serbia reaches $0.16 \%$ (2 313 infected animals).

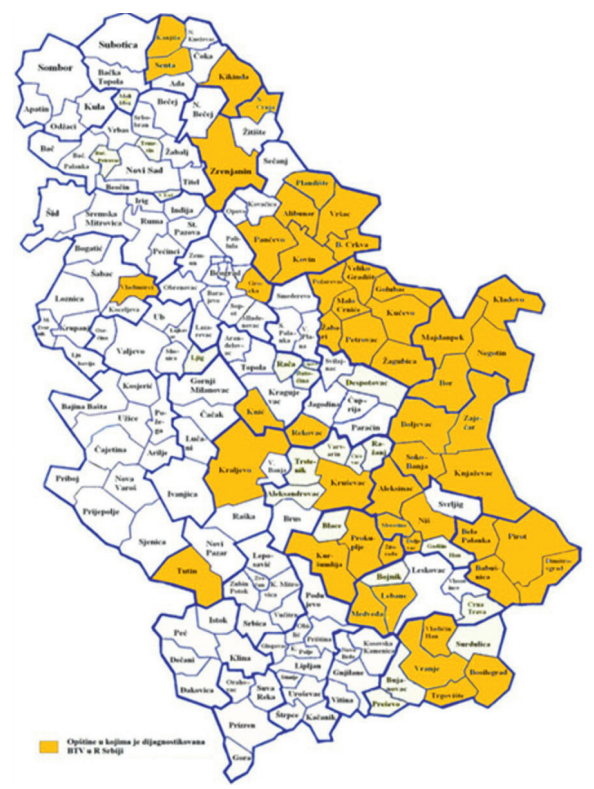

Figure 1. Distribution map of bluetongue cases in territories covered by veterinary institutes in Serbia in 2014

\section{Bluetongue in sheep}

Bluetongue cases in sheep were reported on territories covered by 9 veterinary institutes. From the total number of sheep in Serbia ( $\mathrm{n}=1748$ 110), $58.96 \%(\mathrm{n}=1030 \quad 655)$ were located in areas affected by bluetongue (Table 1). Total of 2083 cases of infected sheep were reported during the investigation period, which represents $0.2 \%$ of the total number of sheep in affected areas. The highest incidence proportion with 1224 cases per 139872 sheep or $0.88 \%$, was recorded in the territory under surveillance of Veterinary Institute of Nis (Table 1).

\section{Bluetongue in cattle}

In cattle, BTV-4 was confirmed in 6 out of 12 areas covered by veterinary institutes. From the total number of cattle in Serbia $(n=920$ 068), $39.28 \%(n=361042)$ were located in areas affected by bluetongue. A total of 206 infected cases per 361042 of cattle were reported, which gives incidence proportion of $0.06 \%$. The highest incidence proportion with 79 cases per 100923 of cattle or $0.08 \%$, was recorded in the territory under surveillance of the Veterinary Institute of Nis.

Table 1. Distribution of bluetongue infection in 2014 on territories under the surveillance of veterinary institutes in Serbia

\begin{tabular}{|c|c|c|c|c|c|c|c|c|}
\hline \multirow{2}{*}{$\begin{array}{l}\text { Veterinary } \\
\text { institute }\end{array}$} & \multicolumn{2}{|c|}{ cattle } & \multicolumn{2}{|c|}{ sheep } & \multicolumn{2}{|c|}{ goats } & \multicolumn{2}{|c|}{$\begin{array}{c}\text { Total } \\
\text { (cattle+sheep+goats) }\end{array}$} \\
\hline & total & infected & total & infected & total & infected & total & infected \\
\hline "Nis" & 100923 & $\begin{array}{c}79 \\
(0.08 \%)\end{array}$ & 139872 & $\begin{array}{c}1224 \\
(0.86 \%)\end{array}$ & 53311 & $16(0.03 \%)$ & 294106 & $\begin{array}{c}1319 \\
(0.45 \%)\end{array}$ \\
\hline “Zajecar" & 35750 & $\begin{array}{c}46 \\
(0.13 \%)\end{array}$ & 78777 & $\begin{array}{c}290 \\
(0.37 \%)\end{array}$ & 16598 & $2(0.012 \%)$ & 131125 & $\begin{array}{c}338 \\
(0.26 \%)\end{array}$ \\
\hline "Pozarevac" & 32528 & $3(0.01 \%)$ & 79452 & $\begin{array}{c}125 \\
(0.16 \%)\end{array}$ & 12299 & $1(0.008 \%)$ & 124279 & $\begin{array}{c}129 \\
(0.10 \%)\end{array}$ \\
\hline "Pancevo" & 27021 & $\begin{array}{c}67 \\
(0.25 \%)\end{array}$ & 48030 & $\begin{array}{c}408 \\
(0.85 \%)\end{array}$ & l & / & 75051 & $\begin{array}{c}475 \\
(0.63 \%)\end{array}$ \\
\hline "Zrenjanin" & 77262 & $5(0.01 \%)$ & 83123 & $14(0.02 \%)$ & 10450 & $5(0.05 \%)$ & 170835 & $24(0.01 \%)$ \\
\hline "Kraljevo" & 87918 & $6(0.01 \%)$ & 165510 & $4(0.002 \%)$ & / & / & 253428 & $\begin{array}{c}10 \\
(0.004 \%)\end{array}$ \\
\hline "Sabac" & l & l & 161878 & $3(0.002 \%)$ & l & l & 161878 & $3(0.002 \%)$ \\
\hline "Jagodina" & l & I & 195049 & $9(0.005 \%)$ & / & I & 195049 & $9(0.005 \%)$ \\
\hline "Beograd" & I & l & 78974 & $6(0.008 \%)$ & l & / & 78974 & $6(0.007 \%)$ \\
\hline Total & 361042 & $\begin{array}{c}206 \\
(0.06 \%)\end{array}$ & 1030655 & $\begin{array}{l}2083 \\
(0.2 \%)\end{array}$ & 92658 & $\begin{array}{c}24 \\
(0.03 \%)\end{array}$ & 1484725 & $\begin{array}{c}2313 \\
(0.16 \%)\end{array}$ \\
\hline
\end{tabular}

total - the total number of animals by species

infected - number and \% of confirmed BTV cases 


\section{Bluetongue in goats}

Bluetongue in goats was confirmed on territories under the surveillance of 4 veterinary institutes. Total of 24 infected cases per 92658 goats were reported, which gives incidence proportion of $0.03 \%$. The highest incidence proportion with 16 cases per 53311 goats or $0.02 \%$, was recorded in the territory under surveillance of the Veterinary Institute of Nis.

\section{Monthly distribution of bluetongue cases}

The highest incidence of BTV in all susceptible species was documented during the period SeptemberDecember 2014, with different incidence rates for each species. Bluetongue cases in cattle and sheep were not recorded only in December and August, respectively. BTV positive goats were reported only in September and October. Results of monthly incidence proportion of bluetongue cases, regardless of the species, showed $94.43 \%$ positive cases in September and October, which is significantly higher compared to other months $(\mathrm{p}<0.01)$. With regards to the species, the highest incidence of BTV and mortality were detected in sheep. Recorded lethality $(\%$, died/infected $\mathrm{x} 100)$ in cattle, sheep and goats was $18.45 \%(38 / 206 \times 100), 48.10 \%(1002 / 2083 \times 100)$ and $54.17 \%$ (13/24 x 100), respectively (Fig. 2A, B). presence and geographic distribution of Culicoides biting midges have proven to be critical aspects in BTV transmission among susceptible animals, and also the limiting factor in occurrence of the disease (3). Prior to 1998, the appearance of BTV infections were limited to a geographic band between the latitudes $40^{\circ} \mathrm{N}$ and $35^{\circ} \mathrm{S}$, habitat of its main vector, C. imicola (14). The breaking point for emergence of bluetongue on the Balkans was the 1998 BTV outbreak on 4 Greek islands $(30,31)$. At the same time, with the exception of Turkey, this was the first report of BTV-9 in this part of the Europe (32). During the following years, in addition to BTV-9, the presence of BTV-1, BTV-2, BTV-4 and BTV-16 was also confirmed $(10,17)$.

The first outbreak of bluetongue in Serbia was reported at the end of 2001, where BTV-9 was detected (23). There is a presumption that BTV-9 reached Serbia through infected host animals from Macedonia, Albania and Bulgaria (10), from where it spread further to Croatia $(33,34)$ and Bosnia and Herzegovina (10). During the outbreak in 2002, bluetongue cases in Serbia were recorded in 37 focal points within 16 municipalities (23). The most recent outbreak of BTV in Serbia was reported at the end of August 2014 (35), and the virus was identified as BTV-4. This was the first report of BTV-4 in Serbia, after which its presence was reported in Montenegro, Bosnia and

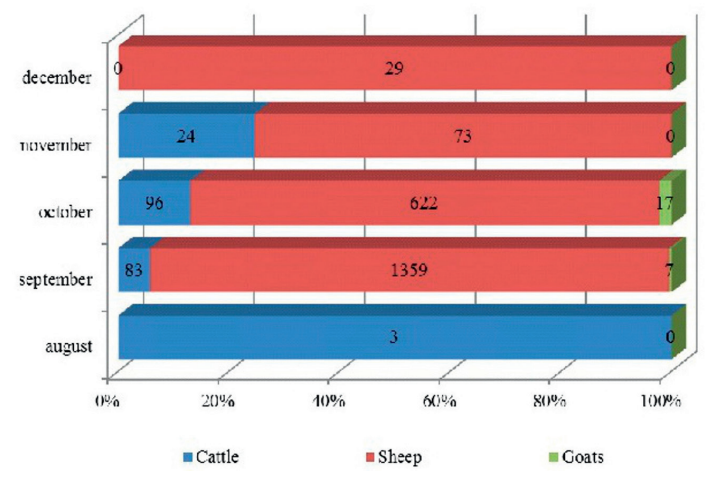

Figure 2A. Morbidity - lethality ratio of bluetongue infected ruminants in Serbia in 2014

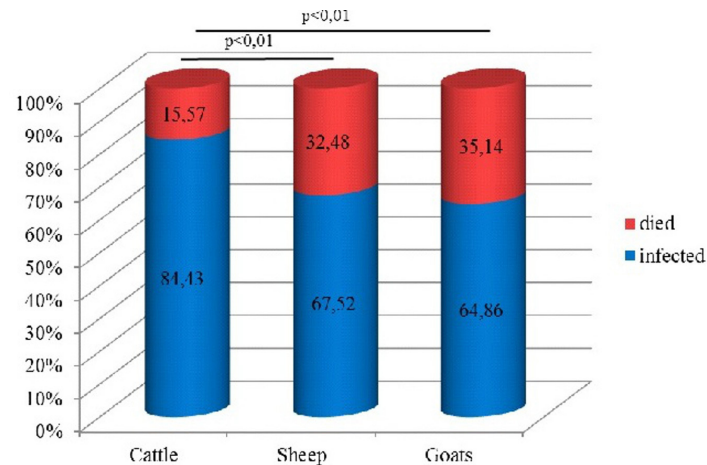

Figure 2B. Morbidity - lethality ratio of bluetongue infected ruminants in Serbia in 2014

\section{DISCUSSION}

During the past 20 years, the distribution and characteristics of BTV infection have changed substantially in Europe. It has been suggested, but not proven, that global climate change is responsible for spreading the areal of BTV vectors and enabling the vector competence to indigenous Culicoides species, which influenced the occurrence of different BTV serotypes in geographic areas above $50^{\circ} \mathrm{N}$ (11). The
Herzegovina and Croatia (36). Outbreaks of BTV-9 and BTV-4 in Serbia are most likely connected to the vector competence of other species of Culicoides other than $C$. imicola (7). Isolation of BTV-9 and BTV-4 from Palaearctic Culicoides species, especially C. obsoletus, C. pulicaris and C. scoticus indigenous to the Balkans (17) supports the hypothesis that other species of biting midges act as primary BTV vectors.

Bluetongue cases in Serbian ruminants were recorded during 644 outbreaks in 49 municipalities, 
i.e. 17 administrative regions covered by 9 veterinary institutes. With regards to the total number of susceptible animals kept in the areas of BTV outbreak recorded in 2014, the overall incidence of BTV in Serbia reaches $0.16 \%$. Individual incidence for sheep, cattle and goats was $0.2 \%, 0.06 \%$ and $0.03 \%$, respectively. This is consistent with the incidence proportions recorded in Greece, Bulgaria and Macedonia (37). BTV-4 outbreak was reported in Croatia and Bosnia and Herzegovina in 2014, but official statistics concerning number of infected and deceased animals has not been available to the authors of this paper.

The highest number of bluetongue cases was documented in September and October. These results support the observation that the highest incidence of BTV corresponds to the period of greatest vector abundance (38). Investigation of the bluetongue outbreak indicated higher number of infected animals in municipalities positioned in the basins of major rivers that flow through Serbia (Danube, Sava, Velika Morava, Timok). Highest number of fatality cases due to BTV infections in Serbia, in 2014, was recorded in sheep, followed by goats and cattle. This is not surprising given that sheep develop the most severe clinical conditions, while cattle are the most susceptible host (10). Surprisingly high lethality recorded in goats is in disagreement with the traditional views that bluetongue in goats and cattle often remains subclinical or exhibits mild and transient signs $(12,13)$.

In comparison with the BTV-9 outbreak in Serbia in 2002, BTV-4 outbreak in 2014 resulted in substantial increase in the number of affected areas. Potential reasons for this could be : (i) spread of Culicoides biting midges with regards to their abundance and vector competence due to climate changes (39); (ii) increase in ungoverned and illegal trade of ruminants from BTV affected surrounding areas (Bulgaria, Macedonia and Albania). For the purpose of increasing the understanding of occurrence and distribution of BTV in Serbia, along with investigation of infected animals, a survey aimed at defining the Culicoides species present in Serbia, their vector competence and infection status is urgently needed.

\section{CONCLUSION}

From the above stated, monitoring of bluetongue disease in Serbia relies on active surveillance programmes aimed at: (i) identification and tracing of susceptible and potentially infected animals and (ii) detection, distribution and prevalence of insect vectors. In addition, restriction and trade bans of ruminants between BTV infected and non-infected areas are conducted. For 2016, vaccination of sheep against BTV is planned to be implemented in areas affected by bluetongue in 2014 and 2015 .

\section{CONFLICT OF INTEREST STATEMENT}

The authors declared that they have no potential conflict of interest with respect to the authorship and/or publication of this article.

\section{ACKNOWLEDGMENT}

This study was supported by the Ministry of Education, Science and Technological Development of the Republic of Serbia (grant No. III 46002).

\section{REFERENCES}

1. Verwoerd, D., Erasmus, B. J. (2004). Bluetongue. In: J. A. Coetzer, R. C. Tustin, (Ed.), Infectious diseases of livestock. 2nd ed. (pp. 1201-1220). Cape Town: Oxford University Press.

2. Maclachlan, N.J., Drew, C.P., Darpel, K.E., Worwa, G. (2009). The pathology and pathogenesis of bluetongue. J Comp Pathol. 141, 1-16. http://dx.doi.org/10.1016/j.jcpa.2009.04.003 PMid:19476953

3. Schwartz-Cornil, I., Mertens, P.P., Contreras, V., Hemati, B., Pascale, F., Breard, E., Mellor, P.S., MacLachlan, N.J., Zientara, S. (2008). Bluetongue virus: virology, pathogenesis and immunity. Vet Res. 39-46. http://dx.doi.org/10.1051/vetres:2008023 PMid:18495078

4. King, A.M.Q., Lefkowitz, E., Adams, M.J., Carstens, E.B. (2012). Family - Reoviridae. Virus Taxonomy. (pp.541-637). San Diego: Elsevier.

5. Maan,N.S.,Maan,S.,Belaganahalli,M.N.,Ostlund,E.N., Johnson, D.J., Nomikou, K., Mertens, P.P. (2012). Identification and differentiation of the twenty six bluetongue virus serotypes by RT-PCR amplification of the serotype-specific genome segment 2. PloS One, 7(2), pp.e32601-e32601.

http://dx.doi.org/10.1371/journal.pone.0032601 PMid:22389711 PMCid:PMC3289656

6. Gibbs, E.P., Greiner, E.C. (1994). The epidemiology of bluetongue. Comp Immunol Microb Infect Dis. 17, 197-206.

http://dx.doi.org/10.1016/0147-9571(94)90044-2 
7. Tabachnick, W.J. (2004). Culicoides and the global epidemiology of bluetongue virus infection. Vet Ital. 40, 145-150.

8. Mellor, P.S., Boorman, J. (1995). The transmission and geographicalspread of African horse sickness and bluetongue viruses. Ann Trop Med Parasit. 89, 1-15. PMid:7741589

9. Darpel, K.E., Batten, C.A., Veronesi, E., Shaw, A.E., Anthony, S., Bachanek-Bankowska, K., Kgosana, L., Bin-Tarif, A., Carpenter, S., Muller-Doblies, U.U., Takamatsu, H.H., Mellor, P.S., Mertens, P.P.C. (2007). Clinical signs and pathology shown by British sheep and cattle infected with bluetongue virus serotype 8 derived from the 2006 outbreak in northern Europe. Vet Rec. 161, 253-261.

http://dx.doi.org/10.1136/vr.161.8.253

PMid:17720961

10. Mellor, P.S., Carpenter, S., Harrup, L., Baylis, M., Mertens, P.P. (2008). Bluetongue in Europe and the Mediterranean Basin: history of occurrence prior to 2006. Prev Vet Med. 87, 4-20.

http://dx.doi.org/10.1016/j.prevetmed.2008.06.002 PMid:18619694

11. Maclachlan, N.J. (2011). Bluetongue: history, global epidemiology, and pathogenesis. Prev Vet Med. 102, 107-111.

http://dx.doi.org/10.1016/j.prevetmed.2011.04.005 PMid:21570141

12. Barratt-Boyes, S.M., MacLachlan, N.J. (1995). Pathogenesis of bluetonguevirus infection of cattle. J Am Vet Med A. 206, 1322-1329. PMid:7775242

13. OIE Disease Information. [Internet]. Bluetongue. http://www.oie.int/fileadmin/Home/eng/Animal_ Health_in_the_World/docs/pdf/Disease_cards/ BLUETONGUE.pdf

14. Sperlova, A., Zendulkova, D. (2011). Bluetongue: a review. Vet Med. 56, 430-452.

15. Anon. (2001a). Bluetongue in Greece and Italy. Off Int Epizoot Dis Info. 14, 215-218.

16. Wilson, A.J., Mellor, P.S. (2009). Bluetongue in Europe: past, present and future. Philos T Roy Soc B. 364, 2669-2681.

http://dx.doi.org/10.1098/rstb.2009.0091

PMid:19687037 PMCid:PMC2865089

17. Saegerman, C., Berkvens, D., Mellor, P.S. (2008). Bluetongue epidemiology in the European union. Emerg Infect Dis. 14, 539-544. http://dx.doi.org/10.3201/eid1404.071441 PMid:18394269 PMCid:PMC2570923
18. Rodríguez-Sánchez, B., Iglesias-Martín, I., Martínez-Avilés, M., Sánchez-Vizcaíno, J.M. (2008). Orbiviruses in the Mediterranean Basin: updated epidemiologicalsituation of Bluetongue and new methods for the detection of BTV serotype 4. Transbound Emerg Dis. 55, 205-214. http://dx.doi.org/10.1111/j.1865-1682.2008.01029.x PMid:18666964

19. Zientara, S., MacLachlan, N.J., Calistri, P., SanchezVizcaino, J.M., Savini, G. (2010). Bluetongue vaccination in Europe. Expert Rev Vaccines. 9, 989-991.

http://dx.doi.org/10.1586/erv.10.97

PMid:20822340

20. De Clercq, K., Mertens, P., De Leeuw, I., Oura, C., Houdart, P., Potgieter, A.C., Maan, S., et al. (2009). Emergence of bluetongue serotypes in Europe. Part 2. The occurrence of a BTV-11 strain in Belgium. Transbound Emerg Dis. 9/10, 355-361. http://dx.doi.org/10.1111/j.1865-1682.2009.01092.x PMid:19909474

21. Eschbaumer, M., Hoffmann, B., Moss, A., Savini, G., Leone, A., Konig, P., Zemke, J., Conraths, F., Beer, M. (2010). Emergence of bluetongue virus serotype 6 in Europe-German field data and experimental infection in cattle. Vet Microbiol. 143, 189-195. http://dx.doi.org/10.1016/j.vetmic.2009.11.040 PMid:20045271

22. Ganter, M. (2014). Bluetongue disease-Global overview and future risks. Small Ruminant Res. 118, 79-85.

http://dx.doi.org/10.1016/j.smallrumres.2013.12.011

23. Djuricic, B., Nedic, D., Lausevic, D., Pavlovic, M. (2004). The epizootiological occurrence of bluetongue in the central Balkans. Vet Ital. 40, 105-107. PMid:20419644

24. Anon. (2001b). Bluetongue in the Former Yugoslav Republic of Macedonia. Off Int Epizoot Dis Info. 14, 234.

25. Mellor, P.S., Wittmann, E.J. (2002). Bluetongue virus in the Mediterranean basin 1998-2001. Vet J. 164, 20-37.

http://dx.doi.org/10.1053/tvj1.2002.0713

PMid:12359482

26. Zientara, S., Sánchez-Vizcaíno, J.M. (2013). Control of bluetongue in Europe. Vet Microbiol. 165, 33-37. http://dx.doi.org/10.1016/j.vetmic.2013.01.010 PMid:23462519

27. OIE - World Organisation for Animal Health [Internet]. 72nd General Session, 23-28 May 2004. http:/www.oie.int/fileadmin/Home/eng/Animal Health_in_the_World/docs/pdf/A_RESO_2004_WP.pdf 
28. OIE - World Organisation for Animal Health [Internet]. Manual of diagnostic tests and vaccines for terrestrial animals. Chapter 2.01.03. Bluetongue, 2014.

http://www.oie.int/fileadmin/Home/fr/Health standards/tahm/2.01.03_BLUETONGUE.pdf

29. Hofmann, M., Griot, C., Chaignat, V., Perler, L., Thür, B. (2008). Bluetongue disease reaches Switzerland. Schweiz Arch Tierheilk, 150, 49-56. http://dx.doi.org/10.1024/0036-7281.150.2.49 PMid:18369049

30. Anon. (1998a). Bluetongue in Greece: confirmation of diagnosis. Dis Info. 11, 166-167.

31. Anon. (1998b). Disease outbreaks reported to the OIE in November-December. Bull Off Int Epizoot. $110,506$.

32. Taylor, W.P., Mellor, P.S. (1994). Distribution of bluetongue virus in Turkey, 1978-81. Epidemiol Infect. 112, 623-633.

http://dx.doi.org/10.1017/S0950268800051323

PMid:8005228 PMCid:PMC2271514

33. Labrovic, A., Poljak, Z., Separovic, S., Jukic, B., Lukman, D., Listes, E., Bosnic, S. (2004). Spatial distribution of bluetongue in cattle in southern Croatia in the last quarter of 2002. Vet Ital. 40, 217-220. PMid:20419667

34. Listes, E., Bosnic, S., Beni, M., Lojkic, M., Cac, Z., Cvetnic, Z., Madic, J., Separovic, S., Labrovic, A., Savini, G., Goffredo, M. (2004). Serological evidence of bluetongue and a preliminary entomological study in southern Croatia. Vet Ital. 40, 221-225. PMid:20419668
35. OIE - World Organisation for Animal Health [Internet]. Bluetongue, Serbia, 2015. [Accessed 30 October 2015.]

http://www.oie.int/wahis_2/public/wahid.php/ Reviewreport/Review?page_refer=MapFullEvent Report\&reportid=15987.

36. OIE - World Organisation for Animal Health [Internet]. Weekly Disease Information, 2015b, [Accessed 30 October 2015].

http://www.oie.int/wahis_2/public/wahid.php/ Diseaseinformation/WI

37. Roberts, H., Smith, J., Batten, C., Nomikou, K., Mertens, P. (2014). Preliminary outbreak assessment - Bluetongue virus (BTV-4) in Greece, Bulgaria and the Republic of Macedonia.

https://www.gov.uk/government/collections/animaldiseases-international-monitoring.

38. Mehlhorn, H., Walldorf, V., Klimpel, S., Schaub, G., Kiel, E., Focke, R., Liebisch, G., Liebisch, A., Werner, D., Bauer, C., Clausen, H., Bauer, B., Geier, M., Hörbrand, T., Bätza, H.J., Conraths, F.J., Hoffmann, B., Beer, M. (2009). Bluetongue disease in Germany (2007-2008): monitoring of entomological aspects. Parasitol Res. 105, 313-319. http://dx.doi.org/10.1007/s00436-009-1416-y PMid:19322587

39. Purse, BV., Mellor, P.S., Rogers, D.J., Samuel, A.R., Mertens, P.P.C., Baylis, M. (2005). Climate change and the recent emergence of bluetongue in Europe. Nat Rev Microbiol. 3, 171-181. http://dx.doi.org/10.1038/nrmicro1090 PMid:15685226

Please cite this article as: Djurić S., Simeunović P., Mirilović M., Stevanović J., Glavinić U., Vejnović B., Stanimirović Z. Retrospective analysis of the bluetongue outbreak in Serbia. Mac Vet Rev 2017; 40 (1): 21-27.

http://dx.doi.org/10.1515/macvetrev-2016-0094 